\title{
Identifikasi Faktor Pengaruh Penggunaan Dompet Digital Menggunakan Metode TAM Dan UTAUT2
}

\author{
Sri Watmah¹, Siti Fauziah², Nuraeni Herlinawati ${ }^{3}$ \\ 1,3IImu Komputer, STMIK Nusa Mandiri Jakarta \\ ${ }^{2}$ Prodi Sistem Informasi, STMIK Nusa Mandiri Jakarta \\ 114002312@nusamandiri.ac.id, 2siti.suz@nusamandiri.ac.id, 3nuraeni.nhw@bsi.ac.id
}

\begin{abstract}
Digital wallets as a method of payment made online using application services. By using a digital wallet service, digital users will find it easier to make transactions, both making payments, and making transfers to other banks with more affordable administrative costs. In addition, using a digital wallet can also make companies grow faster because it is easy to transact both directly and remotely. Several digital wallet service applications currently used in Indonesia include ovo, link aja, dana, and go-pay. This research was conducted to see the factors that influence the use of digital wallets as well as anything that a person desires to take care of a digital wallet with others. This study uses the TAM (Technology Acceptance Model) and UTAUT2 (Unifield Theory Of Acceptance And Use Of Technology) methods. The results show that the variables used in the study, in the form of benefits of digital wallets, social factors, innovation, user satisfaction and recommendations for using digital wallets, are factors that can influence someone using digital wallet services.
\end{abstract}

Keywords: Digital Wallet, TAM, UTAUT2, Ovo, Go-Pay

\begin{abstract}
Abstrak: Dompet digital sebagai salah satu metode pembayaran yang dilakukan secara online dengan menggunakan jasa aplikasi. Dengan menggunkaan layanan dompet digital pengguna akan lebih mudah dalam bertransaksi baik melakukan pembayaran, maupun melakukan trensfer ke bank lain dengan biaya administrasi yang lebih terjangkau. Selain itu dengan menggunakan dompet digital juga dapat membuat perusahaan berkembang lebih cepat karena mudahnya bertransaksi baik untuk bertransaksi secara langsung maupun jarak jauh. Beberapa aplikasi layanan dompet digital yang saat ini digunakan di Indonesia diantaranya ovo, link aja, dana, dan go-pay. Penelitian ini dilakukan untuk mengetahui faktor-faktor yang mempengaruhi seseorang menggunakan layanan dompet digital serta seberapa besar keinginan seseorang untuk merekomendasikan dompet digital kepada orang lain. Penelitian ini menggunakan metode TAM (Technology Acceptance Model) dan UTAUT2 (Unifield Theory Of Acceptance And Use Of Technology). Dari hasil penelitian menunjukan bahwa variabel-variabel yang digunakan dalam penelitian berupa manfaat dompet digital, faktor sosial, inovasi, kepuasan pengguna serta rekomendasi dari penggunaan dompet digital merupakan faktor yang dapat mempengaruhi seseorang menggunkaan layanan dompet digital.
\end{abstract}

Kata kunci: dompet digital, TAM, UTAUT2, ovo, go-pay

\section{A. PENDAHULUAN}

Saat ini penggunaan e-wallet atau dompet digital dalam bisnis nontunai semakin meningkat, hal ini disebabkan oleh efektivitas dan efisiensi yang ditawarkan oleh penyedia jasa dompet digital[Muhammad Taufik Hidayat et al., 2020]. Kerja sama dibidang ekonomi yang sering digambarkan dengan ekonomi berbagi beberapa tahun ini telah megecap kesuksesan besar dengan menggeser prinsip ekonomi yang masih bersifat tradisional. Pertumbuhan teknologi keuangan tertinggi di Indonesia berada pada metode. Metode pembayaran yang saaat ini tengah berkembang dimasyarakat yaitu pembayaran berbasis digital (cashless). Metode pembayaran nontunai saat ini terbagi menjadi dua yaitu pembayaran dengan e-money 
dan e-wallet. E-money merupakan cara pembayaran dengan berfokus pada chip (offline) sedangkan e-wallet atau yang dikenal juga dengan dompet digital merupakan metode pembayaran berbasis server (online) [Mayanti et al., 2020]. Begitu cepatnya perkembangan teknologi informasi komunikasi dan smartphone, teknologi terbarukan dan berbagai aplikasi perangkat lunak telah menjadi bagian penting dalam kehidupan sehari-hari [Dwivedi et al., 2018].

Sekarang ini telah hadir metode pembayaran seluler, pembayaran seluler ini merupakan media pembayaran apa pun yang dilakukan menggunakan perangkat seluler atau yang lebih dikenal dengan istilah dompet digital. Pembayaran seluler menyediakan beberapa jenis pelayanan baik untuk pembayaran jarak jauh maupun pembayaran langsung [de Luna et al., 2019]. Metode pembayaran seluler meliputi layanan dompet yang dapat membantu pengguna dengan berbagai cara serta memfasilitasi pedagang suatu sistem yang mudah dan sederhana dalam penggunaanya. Pembayaran seluler merupakan layanan yang dilakukan menggunakan perangkat seluler. Ada beberapa macam layanan pembayaran jarak jauh dan dekat [Madan and Yadav, 2016]. Dengan adanya metode pembayaran seluler sangat membantu pedagang dalam mendekati calon pelanggan ritel bahkan di lokasi terpencil sekali pun, karena penggunaan pembayaran seluler meningkat pada pelanggan yang berada di lokasi yang jauh di negaranegara besar [Nidhi singh, Shalini Srivastava, 2017]. Pembahasan mengenai penggunaan ewallet atau dompet digital juga telah banyak dilakukan, pada penelitian penggunaan e-wallet menggunakan UTAUT2 diantaranya telah dibahas pada penelitian yang dilakukan dengan responden berasal dari daerah Tangerang selatan dalam penelitian yang dilakukan tidak menggunakan variabel moderasi karena dinilai dapat menurunkan nilai yang dihasilkan, dalam penelitian ini juga tidak menggunakan variabel rekomendasi karena berfokus pada penerimaan pengguna dalam penggunaan e-wallet [Muhammad Taufik Hidayat et al., 2020]. Hasil penelitian menunjukkan bahwa variabel UTAUT2 yaitu kemudahan penggunaan dan manfaat dengan inovasi, adalah faktor terpenting untuk mengukur niat menggunakan dan kepuasan yang dirasakan [Singh et al., 2020]. Saat ini ada banyak platform penyedia dompet digital seperti go-pay, dana, ovo, link aja, dan shopeepay. Namun dalam penelitian ini penulis hanya akan fokus menggunakan tiga jenis dompet digital yaitu go-pay, dana dan ovo. Perkembangan dompet digital di Indonesia terbilang cukup pesat sehingga membuat penulis tertarik untuk mencari tahu faktor-faktor yang mempengaruhi seseorang menggunakan dompet digital serta seberapa besar minat seseorang untuk merekomendasikan dompet digital bagi orang lain berdasarkan pengalaman menggunakan dompet digital. Melihat dari penelitian sebelumnya yang tidak menggunakan variabel moderasi maka dalam penelitian ini penulis menggunakan variabel moderasi untuk menghubungkan beberapa variabel yang lain serta mengkolaborasikan metode TAM dan UTAUT 2 [Oliveira et al., 2016].

\section{B. TINJAUAN PUSTAKA}

\section{Dompet Digital}

E-wallet atau dompet digital merupakan salah satu bentuk penerapan perangkat lunak dalam hal pembayaran , penyimpanan uang serta bermacam-macam transaksi yang dilakukan secara nontunai karena berbasis digital. Penggunaan e-wallet dapat dilakukan dengan menggunakan smartphone atau komputer. E-wallet hampir dapat menggantikan peran dompet fisik karena menawarkan berbagai kemudahan dalam bentuk digital [Muhammad Taufik Hidayat et al., 2020].

Pesatnya perkemabangan bisnis startup telah menginspirasi para pelaku usaha untuk melakukan inovasi dalam layanan finansial digitalnya, seperti Go-Pay dari Go-jek [Hidayatullah et al., 2018]

\section{TAM (Technology Acceptance Model)}

TAM merupakan salah satu teori yang digunakan untuk mengetahui dampak pengguna dalam penerimaan sistem inforamsi baru [Salsabil and Sudyasjayanti, 2020]. TAM terdiri dari 3 konstruk utama yaitu persepsi kegunaan (perceived usefulness), kemudahan penggunaan persepsian (perceived ease of use), dan penggunaan teknologi sesungguhnya (actual technology use) [Hamrul et al., 2013].

1. Persepsi kegunaan (perceived usefulness) didefinisikan sebagai sejauh mana seseorang percaya bahwa menggunakan suatu teknologi akan meningkatkan kinerja pekerjaan. Penelitian-penelitian sebelumnya menunjukkan bahwa konstruk persepsian kegunaan berpengaruh secara positif dan signifikan terhadap penggunaan sistem teknologi informasi 
2. Persepsi kemudahan penggunaan (Percieved ease of use) didefinisikan sebagai sejauh mana seseorang percaya bahwa menggunakan suatu teknologi akan bebas dari usaha. Penelitian-penelitian sebelumnya juga menunjukkan bahwa konstruk persepsi kemudahan penggunaan mempengaruhi persepsi kegunaan, niat dan penggunaan teknologi sesungguhnya.

3. Perilaku penggunaan teknologi sesungguhnya (actual technology use) adalah tindakan menggunakan teknologi sesungguhnya yang dilakukan seorang pemakai teknologi. Konstruk inilah yang akan diukur berdasarkan pengaruh dari konstruk lainnya dan dari hasil pengukuran dapat diketahui apakah penerapan teknologi dapat diterima atau ditolak

\section{UTAUT2}

Model UTAUT 2 dikembangkan pada tahun 2012, terdiri atas tujuh variabel independen, yaitu performance expectancy, effort expectancy, social influence, facilitating conditions, hedonic motivation, price value, dan habit, serta dua variabel dependen, yaitu behavioral intention dan use behavior [Kazemi et al., 2015][Muhammad Taufik Hidayat et al., 2020]. Metode UTAUT 2 (Unified Theory of Acceptance and Use of Technology) adalah model penerimaan pengguna yang berpengaruh dan banyak digunakan dalam melaksanakan riset yang berhubungan dengan penerimaan pengguna terhadap suatu teknologi informasi yang lebih berpusat pada konteks konsumen [Hidayatullah et al., 2018]. UTAUT2 berisi penjelasan secara detail tentang dasar individu dalam menggunakan teknologi informasi. UTAUT2 secara khusus mengusulkan perilaku penggunaan teknologi (USE), niat perilaku penggunaan, kondisi fasilitas, persepsi individu, serta kebiasaan [Ramírez-Correa et al., 2019] Dalam UTAUT2 menerapkan Performance Expectancy, Effort Expectancy,Pengaruh Sosial, Nilai Harga, Motivasi Hedonis, Kebiasaan dari UTAUT 2 dan Perilaku atau niat Niat pengguna [Chopdar et al., 2018]. Variabel yang sering digunakan dalam penelitian menggunakan UTAUT 2 mencakup tiga konstruksi yaitu kemudahan yang dirasakan pengguna, manfaat yang dirasakan dan faktor sosial, serta mengintegrasikannya dengan konstruksi yang mencerminkan perspektif konsumen seperti inovasi dari Teori Difusi Inovasi, risiko yang dirasakan, tekanan untuk menggunakan [Singh et al., 2020].

\section{METODE PENELITIAN}

Penelitian ini menggunakan metode TAM dan UTAUT2. Dalam penelitian ini dibuat quisioner yang berisi 35 butir pertanyaan dari 10 variabel. Quisioner tersebut dibuat dalam google form yang link nya di bagikan melalui berbagai akun sosial media seperti whatsapp, facebook, dan twitter. Setelah dibagikan selama beberapa hari didapat hasil dengan jumlah 104 responden. Data yang telah didapat kemudian diolah menggunakan aplikasi smartPIS untuk mengetahui hasil perhitungan dan untuk menguji hipotesis yang ada. Pada gambar 1 dijelaskan tentang sistematis yang digunakan dalam penelitian ini.

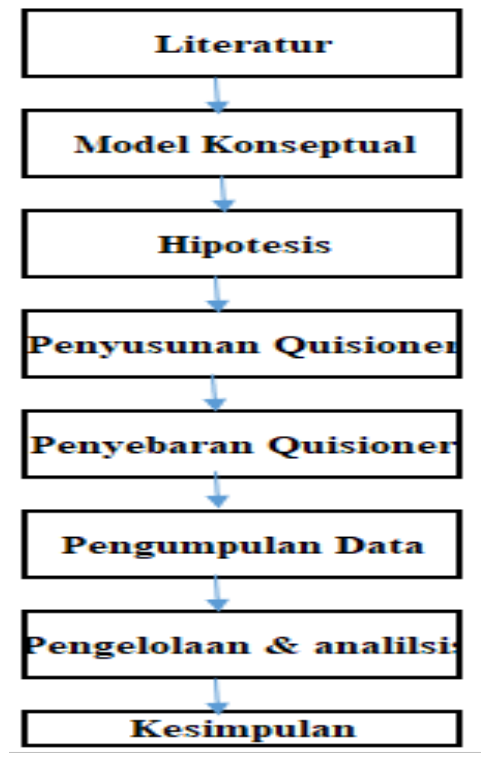

Gambar: 1 Skema metode penelitian 
Gambar 1 menunjukan bahwa penelitian ini menggunakan teori-teori dari jurnal penelitian, buku serta artikel yang menjadi landasan dalam penelitian ini. Model konseptual yang digunakan untuk melihat hubungan antar variabel dalam menentukan hipotesis. Setelah penyusunan dan penyebaran quisioner data yang diperoleh kemudian dioah menggunakan sPLS lalu di analisis sehingga dapat ditarik kesimpulan.

Pada kasus ini ada 3 faktor yang digunakan untuk membuat hipotesis pengguna dalam menggunakan dompet digital, ketiga faktor tersebut yaitu:

\section{Faktor yang mempengaruhi niat pengguna untuk menggunakan teknologi.}

Dari faktor niat penggunaan ini didapatkan 4 hipotesis. Faktor kemudahan dalam penggunaan telah menunjukan hasil yang baik pada banyak studi di beberapa tempat yang berbeda [Choi and Ji, 2015][Madigan et al., 2016]. Kegunaan, pandangan risiko, sikap dan pengaruh sosial. Variabel ini telah digunakan dalam beberapa studi sebelumnya dan telah terbukti bahwa variable tersebut signifikan terhadap teknologi baru [Dwivedi et al., 2019]

Dengan demikian kemudahan penggunaan, manfaat yang dirasakan dan sikap terhadap dompet digital berpengaruh positif terhadap niat pengguna, sedangkan risiko yang akan dihadapi berpengaruh negatif terhadap niat pengguna.

Hipotesis 1: Persepsi kemudahan penggunaan secara positif memengaruhi niat pengguna untuk menggunakan dompet seluler.

Hipotesis 2: Manfaat yang dirasakan secara positif memengaruhi niat pengguna untuk menggunakan dompet digital.

Hipotesis 3: Risiko yang diterima secara negatif memengaruhi niat pengguna untuk gunakan dompet ponsel.

Hipotesi 4: Sikap terhadap dompet digital memiliki pengaruh positif dengan niat menggunakan dompet digital.

\section{b. Niat konsumen, kepuasan dan rekomendasi}

Beberapa penelitian yang telah dilakukan sebelumnya membenarkan interaksi langsung dan tidak langsung antara persepsi kepuasan dan niat pengguna [Nidhi singh, Shalini Srivastava, 2017] [Brand et al., 2017]. Kepuasan yang dirasakan oleh pelanggan disebabkan oleh keuntungan dan ketidaknyamanan teknologi [Casidy and Wymer, 2016].

Merekomendasikan suatu teknolologi merupakan perilaku pengguna, kemauan pengguna, dan kepuasan pengguna yang menerima atau menyetujui penggunaan teknologi baru. Dewasa ini sudah sangat popular untuk melakukan review penggunaan teknologi di berbagai media social [Oliveira et al., 2016].

Hipotesis 5: Semakin besar niat pengguna untuk menggunakan, semakin besar persepsi kepuasan dengan layanan dompet digital.

Hipotesis 6: Semakin besar kepuasan yang dirasakan pengguna dompet digital, semakin besar rekomendasi pengguna untuk menggunakan layanan dompet digital.

c. Efek moderat dari inovasi, tekankan (stress) untuk menggunakan dan pengaruh sosial

Dalam studi ini menggunakan variabel 3 moderasi yang menghubungkan variable dependent dan independent. Variabel inovasi dan stress akan memoderasi pengaruh niat pengguna dan kepuasan pengguna. Dan variabel sosial yang akan memoderat kepuasan yang dirasakan pengguna dan rekomendasi untuk menggunakan layanan dompet digital.

Hipotesis 7: Inovasi memoderasi hubungan di antara keduanya niat pengguna dan kepuasan yang dirasakan dengan dompet ponsel.

Hipotesis 8: Stres memoderasi hubungan antara niat pengguna dan kepuasan yang dirasakan dengan dompet ponsel.

Hipotesis 9: Pengaruh sosial memoderasi hubungan antara kepuasan dan rekomendasi yang dirasakan pengguna untuk menggunakan dompet digital.

Gambar 2 dibawah ini menunjukan skema pemodelan dari hipotesis yang digunakan dalam penelitian ini. dalam gambar ada 9 hipotesis yang digunakan dengan tiga diantaranya merupakan variabel moderasi yang disimbolkan dengan garis putus-putus. 


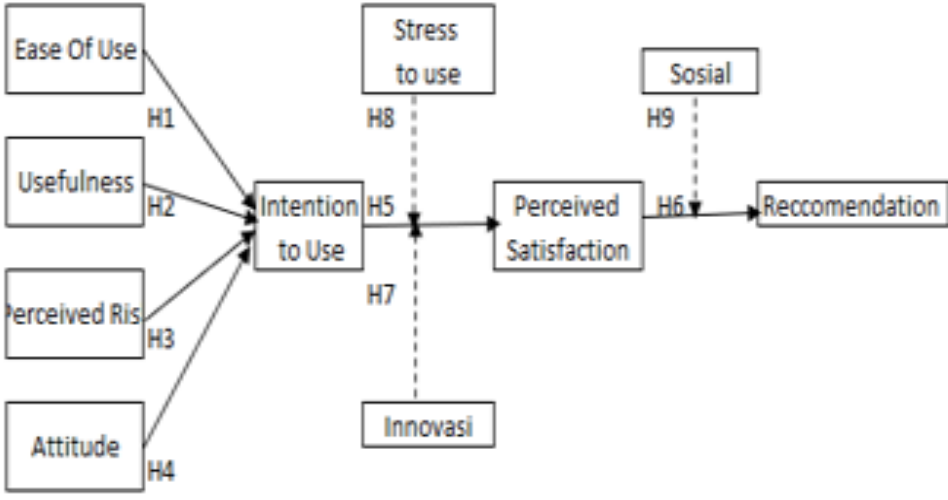

Gambar 2. Model dan Hipotesis Penelitian

\section{HASIL DAN PEMBAHASAN}

Berikut ini merupakan tabel profil responden yang didapat dari hasil quisioner yang sebelumnya telah diisi oleh responden secara online di googleform. Pada tabel tersebut menunjukan atribut demografi repsonden, frekuensi dan persentase.

\section{Tabel 1: Profil Responden}

\begin{tabular}{|c|c|c|c|}
\hline \multicolumn{2}{|c|}{ Demoghraphic Attributes } & Frequences & Percent \\
\hline \multirow[t]{2}{*}{ Gender } & Laki-laki & 61 & $58,70 \%$ \\
\hline & Perempuan & 43 & $41,30 \%$ \\
\hline \multirow[t]{3}{*}{ Usia } & $20-30$ tahun & 81 & $77,90 \%$ \\
\hline & $31-40$ tahun & 17 & $16,30 \%$ \\
\hline & $41-50$ tahun & 6 & $5,80 \%$ \\
\hline \multirow{5}{*}{ Pendapatan } & $<2$ Juta & 32 & $30,80 \%$ \\
\hline & 2 Juta & 7 & $6,70 \%$ \\
\hline & 5-6 Juta & 38 & $36,50 \%$ \\
\hline & 3-4 Juta & 27 & $26 \%$ \\
\hline & $>6$ Juta & - & $0 \%$ \\
\hline \multirow{4}{*}{ Pekerjaan } & Karyawan & 65 & $62,50 \%$ \\
\hline & Pengusaha & 1 & $1 \%$ \\
\hline & Pelajar & 30 & $28,80 \%$ \\
\hline & Lainnya & 8 & $7,70 \%$ \\
\hline \multirow[t]{2}{*}{ Menggunakan Samartphone } & $\mathrm{Ya}$ & 103 & $99 \%$ \\
\hline & Tidak & 1 & $1 \%$ \\
\hline \multirow{5}{*}{ Waktu penggunaan Smartphone } & $<6$ Bulan & 3 & $2,90 \%$ \\
\hline & $<1$ Tahun & 4 & $3,80 \%$ \\
\hline & 1-3 Tahun & 13 & $12,50 \%$ \\
\hline & 3-5 Tahun & 22 & $21,20 \%$ \\
\hline & >5Tahun & 62 & $59,60 \%$ \\
\hline \multirow{3}{*}{$\begin{array}{l}\text { Mengetahui Smartphone dapat } \\
\text { dijadikan alat pembayaran } \\
\text { Mengetahui Smartphone diperlukan }\end{array}$} & $\mathrm{Ya}$ & 97 & $93,30 \%$ \\
\hline & Tidak & 7 & $6,70 \%$ \\
\hline & $\mathrm{Ya}$ & 97 & $93,30 \%$ \\
\hline
\end{tabular}




\begin{tabular}{|l|l|c|c|} 
untuk dompet digital & Tidak & 7 & $6,70 \%$ \\
\hline Layanan dompet digital yang saat ini digunakan & Dana & 36 & $34,60 \%$ \\
\cline { 2 - 4 } & OVO & 69 & $66,30 \%$ \\
\cline { 2 - 4 } & Go-Pay & 45 & $43,30 \%$ \\
\cline { 2 - 4 } & Lainnya & 25 & $24 \%$ \\
\hline
\end{tabular}

Ada dua langkah yang harus dilakukan untuk melakukan evaluasi data dari kuesioner yaitu pertama adalah evaluasi model pengukuran untuk mengukur reliabilitas dan validitas instrumen penelitian, tahap selanjutnya adalah evaluasi model struktural untuk menguji hipotesis penelitian [Anderson and Gerbing, 1988]. Hasil pengujian validitas yang ada pada table 2 dihitung dengan menggunakan smartPLS 3 . Pada table menunjukan bahwa ada 3 indikator yang dibuang. Indikator E2 yang ada pada variabel sosial dan indicator G2 dan G3 yang ada pada variabel Inovasi, dibuang dari model karena mempunyai nilai lebih kecil dari 0,5.

Pada table 2 nilai Composite Reliability (CR) dan nilai Cronbach's Alpha berada di angka lebih dari 0,7 hal tersebut menunjukan konsistensi internal yang tinggi dalam mengukur variabel latennya. Sehingga dapat dikatakan bahwa indikator-indikator yang digunakan sudah mempunyai reliability yang kuat sehingga mampu mengukur variabelnya.

Pengujian validitas diskriminan outer model dilakukan dengan membandingkan akar AVE dengan nilai korelasi variabel seperti yang ada pada gambar 3. Pada table menunjukan bahwa nilai AVE lebih besar dibandingkan dengan nilai korelasi antar variabel, ini menunjukan bahwa variabel memiliki validitas diskriminan yang cukup tinggi.

Table 2: Uji Validitas

\begin{tabular}{|c|c|c|c|c|c|}
\hline Variabel & Item & $\begin{array}{c}\text { Outer } \\
\text { Loading }\end{array}$ & $\mathbf{C R}$ & CA & AVE \\
\hline \multirow{4}{*}{$\begin{array}{l}\text { Easy Of Use } \\
\text { (EOU) }\end{array}$} & $\mathrm{A} 1$ & 0.901 & 0,938 & 0,913 & 0,792 \\
\hline & A2 & 0.886 & & & \\
\hline & A3 & 0.886 & & & \\
\hline & A4 & 0.887 & & & \\
\hline \multirow{4}{*}{$\begin{array}{l}\text { Usefulness } \\
\text { (UF) }\end{array}$} & B1 & 0.890 & 0,944 & 0,922 & 0,809 \\
\hline & B2 & 0.869 & & & \\
\hline & B3 & 0.917 & & & \\
\hline & B4 & 0.921 & & & \\
\hline \multirow[t]{4}{*}{ Risk (RISK) } & $\mathrm{C} 1$ & 0.885 & 0,926 & 0,898 & 0,757 \\
\hline & $\mathrm{C} 2$ & 0.897 & & & \\
\hline & $\mathrm{C} 3$ & 0.907 & & & \\
\hline & $\mathrm{C} 4$ & 0.786 & & & \\
\hline \multirow{4}{*}{$\begin{array}{l}\text { Attitude } \\
\text { (ATTD) }\end{array}$} & D1 & 0.822 & 0,922 & 0,886 & 0,746 \\
\hline & $\mathrm{D} 2$ & 0.865 & & & \\
\hline & D3 & 0.864 & & & \\
\hline & D4 & 0.903 & & & \\
\hline \multirow[t]{3}{*}{ Sosial } & E1 & 0.879 & 0,933 & 0,892 & 0,822 \\
\hline & E3 & 0.936 & & & \\
\hline & E4 & 0.901 & & & \\
\hline \multirow{3}{*}{$\begin{array}{l}\text { Intention to } \\
\text { use (ITU) }\end{array}$} & $\mathrm{F} 1$ & 0.823 & 0,89 & 0,816 & 0,746 \\
\hline & $\mathrm{F} 2$ & 0.905 & & & \\
\hline & F3 & 0.834 & & & \\
\hline
\end{tabular}




\begin{tabular}{|c|c|c|c|c|c|}
\hline $\begin{array}{l}\text { Innovasi } \\
\text { (INOV) }\end{array}$ & G1 & 0.989 & 1 & 1 & 1 \\
\hline \multirow{3}{*}{$\begin{array}{l}\text { Stress } \\
\text { (STRES) }\end{array}$} & H1 & 0.981 & 0,926 & 0,949 & 0,807 \\
\hline & $\mathrm{H} 2$ & 0.812 & & & \\
\hline & $\mathrm{H} 3$ & 0.893 & & & \\
\hline \multirow{4}{*}{$\begin{array}{l}\text { perceived } \\
\text { satisfaction } \\
\text { (PS) }\end{array}$} & I1 & 0.953 & 0,977 & 0,969 & 0,915 \\
\hline & $\mathrm{I} 2$ & 0.961 & & & \\
\hline & I3 & 0.961 & & & \\
\hline & $\mathrm{I} 4$ & 0.951 & & & \\
\hline \multirow{3}{*}{$\begin{array}{l}\text { Recommended } \\
\text { (RECOM) }\end{array}$} & $\mathrm{J} 1$ & 0.910 & 0,932 & 0,891 & 0,821 \\
\hline & $\mathrm{J} 2$ & 0.920 & & & \\
\hline & $\mathrm{J} 3$ & 0.889 & & & \\
\hline
\end{tabular}

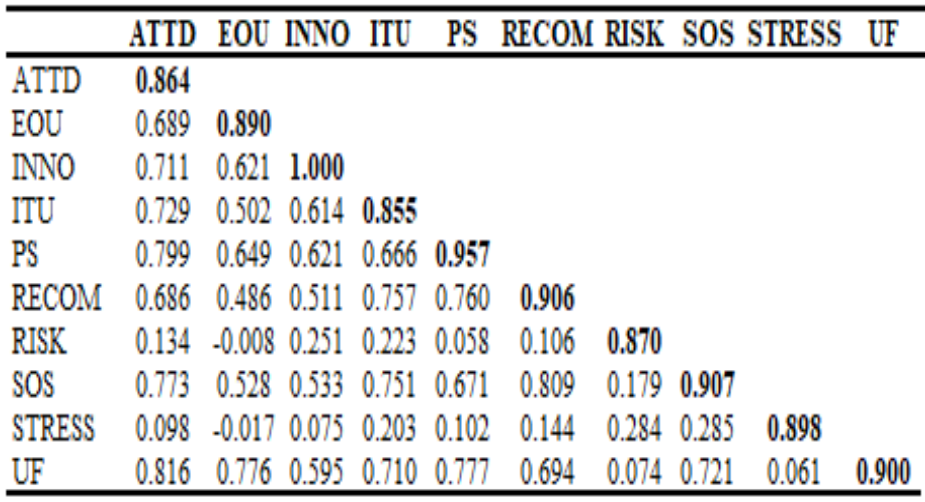

Gambar 3: Uji Validitas Diskriminan Outer Model

Pada table 3 menunjukan ringkasan hasil pengujian hipotesis dari peneliti yang menggunakan pengujian structural pada SPLS. Dari 6 hipotesis 4 diterima dan 2 diantaranya ditolak.

Tabel 3: Uji Hipoteis Model

\begin{tabular}{|l|l|l|r|l|l|}
\hline & Hipotesis & $\begin{array}{c}\text { Original } \\
\text { Sample }\end{array}$ & $\begin{array}{c}\text { T } \\
\text { Statistics }\end{array}$ & \multicolumn{1}{|c|}{ Signif } & Kesimpulan \\
\hline H1 & EOU-ITU & -0.164 & 1.236 & 0.217 & Ditolak \\
\hline H2 & UF-ITU & 0.462 & 2.345 & 0.019 & Diterima \\
\hline H3 & RISK-ITU & 0.127 & 1.519 & 0.129 & Ditolak \\
\hline H4 & ATTD-ITU & 0.448 & 3.686 & 0.000 & Diterima \\
\hline H5 & ITU-PS & 0.438 & 2.876 & 0.004 & Diterima \\
\hline H6 & PS-RECOM & 0.437 & 4.974 & 0.000 & Diterima \\
\hline
\end{tabular}

Hipotesis kemudahan dalam penggunaan dompet digital (EOU) berpengaruh positif terhadap niat untuk menggunakan dompet digital (ITU) pada table 3 menunjukan indikasi ditolak, hal ini dikarenakan penggunaan dompet digital harus didukung dengan aplikasi yang terinstal di smartphone dan tehubung ke internet, kondisi jaringan yang terkadang tidak stabil mempengaruhi penggunaan dompet digital. Hipotesis yang kedua yaitu manfaat penggunaan dompet digital (UF) berpengaruh positif terhadap niat untuk menggunakan dompet digital (ITU). Jika dilihat dari segi manfaat dompet digital tergolong lebih sederhana untuk bertransaksi apalagi sekarang ini penawaran dompet digital dengan menggunakan banyak diskon atau cashback 
untuk menarik penggunaan dompet digital. Hipotesis yang ketiga yaitu resiko yang diterima (RISK) secara negative mempengaruhi niat menggunakan dompet digital (ITU) dalam table 3 menunjukan ditolak, hal tersebut karena pengguna masih belum yakin akan keamanan bertransaksi menggunakan dompet digital. Hipotesis yang ke empat yaitu sikap penggunaan dompet digital (ATTD) berpengaruh positif terhadap penggunaan dompet digital (ITU) pada table 3 menunjukan bahwa hipotesisi diterima hal ini dipengaruhi karena dompet digital terbilang unik dan sederhana dalam penggunaannya. Hipotesis yang ke lima yaitu semakin besar niat pengguna untuk menggunakan dompet digital (ITU) berpengaruh positif terhadap kepuasan penggunaan dompet digital (PS) hipotesis ini diterima karena semakin besar niat pengguna untuk menggunakan dompet digital sejalan dengan kepuasan dalam penggunaan dompet digital. Hipotesis yang ke 6 yaitu semakin besar kepuasan yang dirasakan oleh pengguna dompet digital (PS) akan meningkatkan rekomendasi untuk menggunakan dompet digital (RECOM), dalam tabel menunjukan hipotesis diterima.

Tabel 4: Uji Hipotesis Variabel Moderasi

\begin{tabular}{|l|l|l|c|c|}
\hline & $\begin{array}{c}\text { Variabel } \\
\text { Moderat }\end{array}$ & $\begin{array}{c}\text { Original } \\
\text { Sample }\end{array}$ & $\begin{array}{c}\text { T } \\
\text { Statistics }\end{array}$ & Signifikan \\
\hline H7 & INOVASI & 0.383 & 2.470 & 0.014 \\
\hline H8 & STRESS & -0.012 & 0.087 & 0.930 \\
\hline H9 & SOSIAL & 0.534 & 6.404 & 0.000 \\
\hline
\end{tabular}

Dalam studi ini ada variabel moderasi yang digunakan, yaitu inovasi, stress untuk menggunakan dan sosial. Dimana variabel inovasi dan stress untuk menggunakan memoderasi antara niat pengguna dan kepuasan yang dirasakan pengguna dompet digital, variabel sosial memoderasi kepuasan yang dirasakan pengguna dompet digital terhadap rekomendasi untuk menggunakan dompet digital. Pada tabel 4 nilai signifikan variabel inovasi 0,014 hal ini menunjukan bahwa inovasi berpengaruh antara niat pengguna terhadap kepuasan penggunaan dompet digital. Variabel stress untuk menggunakan mempunyai nilai signifikan 0,930 hal ini menunjukan bahwa stress atau tekankan untuk menggunakan dompet digital tidak berpengaruh terhadap niat pengguna dompet digital dan kepuasan yang dirasakan pengguna dompet digital. Variabel sosial mempunyai nilai signifikan 0,000 hal ini menunjukan bahwa lingkungan sosial berpengaruh terhadap kepuasan pengguna untuk merekomendasikan dompet digital.

\section{E. KESIMPULAN}

Dari hasil studi yang dilakukan dengan menggunakan metode TAM dan UTAUT 2 terhadap penggunaan dompet digital yang dilakukan terhadap 104 responden menghasilkan bahwa faktor manfaat dari penggunaan dompet digital dan sikap pengguna dompet digital berpengaruh terhadap niat penggunaan dompet digital. Selain itu niat seseorang terhadap layanan dompet digital berpengaruh terhadap kepuasan pengguna dompet digital. Dari kepuasan penggunaan dompet digital tersebut secara signifikan berpengaruh terhadap pengguna untuk merekomendasikan layanan dompet digital kepada orang-orang terdekat seperti keluarga atau teman. Inovasi dari layanan dompet berbasis digital ini juga menunjang seseorang untuk tertarik menggunakan dompet digital dan berpengaruh terhadap kepuasan pengguna dompet digital. Faktor lingkungan sosial juga secara signifikan berpengaruh terhadap kepuasan seseorang untuk merekomendasikan layanan dompet digital. Kemudian variabel moderasi sosial memberi nilai paling signifikan bagi pengguna dompet digital untuk merekomendasikan penggunaan dompet digital.

\section{REFERENSI}

Anderson JC, Gerbing DW. 1988. Structural Equation Modeling in Practice: A Review and Recommended Two-Step Approach. Psychol. Bull. 103: 411-423.

Brand P, Tajvidi M, Wang Y, Hajli N, Love PED. 2017. Cronfa - Swansea University Open Access Repository Computers in Human Behavior Cronfa URL for this paper: Paper: Released under the terms of a Creative Commons Attribution Non-Commercial No 
Derivatives License ( CC-BY-NC- Computers in Human Behavior Bra.

Casidy R, Wymer W. 2016. A risk worth taking: Perceived risk as moderator of satisfaction, loyalty, and willingness-to-pay premium price. J. Retail. Consum. Serv. 32: 189-197.

Choi JK, Ji YG. 2015. Investigating the Importance of Trust on Adopting an Autonomous Vehicle. Int. J. Hum. Comput. Interact. 31: 692-702.

Chopdar PK, Korfiatis N, Sivakumar VJ, Lytras MD. 2018. Mobile shopping apps adoption and perceived risks: A cross-country perspective utilizing the Unified Theory of Acceptance and Use of Technology. Comput. Human Behav. 86: 109-128.

Dwivedi YK, Rana NP, Jeyaraj A, Clement M, Williams MD. 2019. Re-examining the Unified Theory of Acceptance and Use of Technology (UTAUT): Towards a Revised Theoretical Model. Inf. Syst. Front. 21: 719-734.

Dwivedi YK, Shareef M, Simintiras A, Lal B, Weerakkody VJ. 2018. A generalised adoption model for services: A cross- country comparison of mobile health ( $\mathrm{m}$-health ) The University of Bradford Institutional Repository. 33: 174-187.

Hamrul H, Soedijono B, Amborowati A. 2013. Analisis Perbandingan Metode TAM Dan UTAUT dalam Mengukur Kesuksesan Penerapan Sistem Informasi Akademik (Studi Kasus Penerapan Sistem Informasi STMIK Dipanegara Makassar). Semin. Nas. Inform. 2013 2013: 140-146.

Hidayatullah S, Waris A, Devianti RC. 2018. Perilaku Generasi Milenial dalam Menggunakan Aplikasi Go-Food. J. Manaj. Dan Kewirausahaan 6: 240-249.

Kazemi H, Miller D, Mohan A, Griffith Z, Jin Y, Kwiatkowski J, Tran L, Crawford M. 2015. $350 \mathrm{~mW}$ G-band medium power amplifier fabricated through a new method of 3D-copper additive manufacturing. 2015 IEEE MTT-S Int. Microw. Symp. IMS 2015 36: 157-178.

de Luna IR, Liébana-Cabanillas F, Sánchez-Fernández J, Muñoz-Leiva F. 2019. Mobile payment is not all the same: The adoption of mobile payment systems depending on the technology applied. Technol. Forecast. Soc. Change 146: 931-944.

Madan K, Yadav R. 2016. Behavioural intention to adopt mobile wallet: a developing country perspective. J. Indian Bus. Res. 8: 227-244.

Madigan R, Louw T, Dziennus M, Graindorge T, Ortega E, Graindorge M, Merat N. 2016. Acceptance of Automated Road Transport Systems (ARTS): An Adaptation of the UTAUT Model. Transp. Res. Procedia 14: 2217-2226.

Mayanti R, Managemen M, Informasi S, Gunadarma U, Barat J, Expectancy E, Conditions F, Digital D, Pembayaran T, Indonesian QR. 2020. User Terhadap Penerapan Quick Response Indonesia Standard Sebagai Teknologi Pembayaran Pada. J. Ilm. Ekon. Bisnis Vol. 25: 123-135.

Muhammad Taufik Hidayat, Qurrotul Aini, Elvi Fetrina. 2020. Penerimaan Pengguna E-Wallet Menggunakan UTAUT 2 (Studi Kasus). J. Nas. Tek. Elektro dan Teknol. Inf. 9: 239-247.

Nidhi singh, Shalini Srivastava NS. 2017. International Journal of Bank Marketing Consumer preference and satisfaction of M-Wallets: a study on North Indian consumers. Int. J. Bank Mark. 12: 1-32.

Oliveira T, Thomas M, Baptista G, Campos F. 2016. Mobile payment: Understanding the determinants of customer adoption and intention to recommend the technology. Comput. Human Behav. 61: 404-414.

Ramírez-Correa P, Rondán-Cataluña FJ, Arenas-Gaitán J, Martín-Velicia F. 2019. Analysing the acceptation of online games in mobile devices: An application of UTAUT2. J. Retail. Consum. Serv. 50: 85-93.

Salsabil S, Sudyasjayanti C. 2020. Niat Menggunakan Go Pay Pada Generasi Y Di Surabaya. 4: 310-319.

Singh N, Sinha N, Liébana-Cabanillas FJ. 2020. Determining factors in the adoption and recommendation of mobile wallet services in India: Analysis of the effect of innovativeness, stress to use and social influence. Int. J. Inf. Manage. 50: 191-205. 